\title{
The Effects of Essential Minerals in Different Cations and Anion Forms on Assimilation of Macro and Micronutrients in Soybean Leaves
}

\author{
Goli Mudlagiri, Pande Manju, Mann Marderius \\ Natural Sciences and Environmental Health, Mississippi Valley State University, Itta Bena, MS, USA \\ Email: emby1234@gmail.com
}

How to cite this paper: Mudlagiri, G., Manju, P. and Marderius, M. (2020) The Effects of Essential Minerals in Different Cations and Anion Forms on Assimilation of Macro and Micronutrients in Soybean Leaves. Agricultural Sciences, 11, 332-341. https://doi.org/10.4236/as.2020.113019

Received: February 15, 2020

Accepted: March 16, 2020

Published: March 19, 2020

Copyright $\odot 2020$ by author(s) and Scientific Research Publishing Inc. This work is licensed under the Creative Commons Attribution International License (CC BY 4.0).

http://creativecommons.org/licenses/by/4.0/

\begin{abstract}
In our present study, we have investigated the acquisition of minerals into soybean leaves as affected by application of various minerals in different forms of positive and negative ions. A greenhouse experiment was conducted including the following 11 treatments applied to the soil: potassium nitrate $\left(\mathrm{KNO}_{3}\right)$, potassium iodide $(\mathrm{KI})$, potassium chloride $(\mathrm{KCl})$, sodium chloride $(\mathrm{NaCl})$, calcium, magnesium and ammonium nitrates $\left[\mathrm{Ca}\left(\mathrm{NO}_{3}\right)_{2}, \mathrm{Mg}\left(\mathrm{NO}_{3}\right)_{2}\right.$ and $\mathrm{NH}_{4} \mathrm{NO}_{3}$ ] and ammonium dihydrogen phosphate $\mathrm{NH}_{4}\left(\mathrm{H}_{2} \mathrm{PO}_{4}\right), \mathrm{Na}_{2} \mathrm{SO}_{4}$, ammonium sulfate $\left(\mathrm{NH}_{4}\right)_{2} \mathrm{SO}_{4}$, and disodium phosphate $\mathrm{Na}_{2}\left(\mathrm{HPO}_{4}\right)$. Besides essential minerals, KI was also included as part of this comprehensive study, since according to some reports, molecular iodine $\left(\mathrm{I}^{2}\right)$ and KI may have positive effect on growth and increased stress tolerance in some species of plants. Soybean seeds were sown in pots arranged in twelve groups $/ 3$ replicates in each group including control. At V3 stage the plants were treated with 30 $\mathrm{mmol} /$ pot of the proper chemicals. Ten days after the treatments, leaves were sampled and were dried, analyzed for 5 macro $(\mathrm{K}, \mathrm{P}, \mathrm{S}, \mathrm{Ca} \& \mathrm{Mg})$ and micronutrients (B, $\mathrm{Cu}, \mathrm{Fe}, \mathrm{Mn}, \mathrm{Zn}$ and $\mathrm{Na}$ ). The results showed that of all the 11 treatments, KI (T4) application increased the maximum number of mineral nutrients in leaves, which increased $\mathrm{K}$ by $31.9, \mathrm{Mg}$ by 8 , $\mathrm{P}$ by 60.8 , $\mathrm{S}$ by 38.7 respectively. KI treatment also reported increased micro minerals by $\mathrm{B}, \mathrm{Cu}$, and $\mathrm{Zn}$ were $53.6 \%, 36.3 \%$ and $10.8 \%$ respectively. Similarly, $\mathrm{KNO}_{3}$ (T1) application increased several macro and micronutrients in leaves. We made an attempt to investigate the effects of various other cations like $\mathrm{K}^{1+} \mathrm{vs} \mathrm{Na}^{1+}$, and $\mathrm{NH}_{4}^{+}, \mathrm{Ca}^{2+}$ vs $\mathrm{Mg}^{2+}$; and Anion comparisons $\mathrm{I}^{1-}$ vs $\mathrm{NO}_{3}^{1-}, \mathrm{Cl}^{1-}, \mathrm{H}_{2} \mathrm{PO}_{4}^{1}$; $\mathrm{SO}_{4}^{2-}$ vs $\left(\mathrm{HPO}_{4}\right)^{2-}$ in the present investigation. After reviewing our results, of all the 11 (eleven), treatments studied in our present study, $\mathrm{T} 1\left(\mathrm{KNO}_{3}\right), \mathrm{T} 4(\mathrm{KI})$ and $\mathrm{T} 10 \mathrm{Ca}\left(\mathrm{NO}_{3}\right)_{2}$ applications proved to be the most efficient treatments by affecting the uptake of several minerals in soybean leaves.
\end{abstract}




\section{Keywords}

Cations, Anions, Macronutrients, Micronutrients, Essential Minerals

\section{Introduction}

Soybean is an important source of plant-based protein for humans and animal feed. The soybean seed composition consists of an enormous amount of nutritional substances, valuable for human consumption. Soybeans have the highest protein content and a significant amount of dietary minerals and vitamins. Soybean oil is another valuable product used in food industry accounting for $56 \%$ of global oilseed production; the United States accounts for $36.7 \%$ of world soybean crop production [1] [2]. The demand for soybean production stays strong as it is used in the formulation of various food and industrial products [2]. Soybean crop production could be greatly impacted by any mineral deficiency in the soil by natural or agricultural practices.

There are seventeen essentially important nutrients that plants must obtain from their environment to successfully complete their life cycle. Besides carbon, hydrogen and oxygen, which plants acquire from air and water, the other minerals the plants must acquire from the soil [3]. The soil in which the plants grow, generally contains all nutrients; however nutrients can become limiting or deficient by means of leaching or crop removal. Under certain conditions, nutrients especially in their cation form can be tightly bound to the soil which again can limit their availability to the plants. Applications of mineral fertilizer or biofortification are considered complementary approaches to the conventional breeding [4] [5] [6] [7]. Nutrient management and biofortification are great agricultural tools to combine high yield with high nutrient density (protein, minerals and vitamins) at low cost as adapted by farmers [8] [9] [10].

Understanding the nutrient movement in soil and uptake by plants either in anion or cation forms could help the crop growers choose the application of nutrients as per the demand of the crop to limit the environmental impact while increasing the effectiveness of the fertilizer. Besides, the 17 essential elements listed, there are other minerals regarded as beneficial elements which have been reported to have positive influence on plants but might have been neglected for a long time; those elements are iodine and sodium. Iodine is not an essential element for land plants, although some studies have reported beneficial effects including better growth, changes in tolerance to stress and its antioxidant capacity. Umaly and Poel (1970) have studied the effects of various concentrations of iodine as potassium iodide on the growth of barley, tomato and pea in nutrient solution cultures [11]. This study found enhancement in height, number of tillers and in fresh and dry weights of barley; however, the higher concentrations of $10.0 \mathrm{ppm}$ had decreased growth and developed toxicity symptoms. In humans, iodine is essential for thyroid functioning, and in development of cogni- 
tive abilities, hence use of iodine in agricultural practices for biofortification of crops seems to be an important area for research [12] [13].

The earlier studies done in our lab [14] in an attempt to investigate the effect of different chemical nutrient applications on soybean plants showed considerable modulation of leaf and seed mineral nutrient concentration by increasing several leaf and seed mineral content such as $\mathrm{Cu}, \mathrm{Zn}, \mathrm{Mo} \mathrm{B}, \mathrm{K}, \mathrm{N}, \mathrm{P}, \mathrm{Mg}$ and $\mathrm{S}$ in several treatment groups. Based on our earlier promising results, our present investigation was extended to incorporate a more extensive approach in the study of essential minerals consisting of both cations and anion forms including the two beneficial elements $\mathrm{KI}$ and $\mathrm{NaCl}$.

\section{Material and Methods}

\subsection{Experimental Design}

A greenhouse experiment was conducted at Mississippi Valley State University, Itta Bena, Mississippi, USA (latitude of N $33^{\circ} 28^{\prime}$ and longitude W $90^{\circ} 20$ ). Soybean cultivar Bolivar (maturity group V) was planted in 34 pots (4 gallons). The pots were divided and labeled into 12 treatment groups, each group consisting of 3 replicates; Control (C), $\mathrm{KNO}_{3}$ (T1), $\mathrm{NH}_{4} \mathrm{NO}_{3}$ (T2), $\mathrm{NH}_{4} \mathrm{H}_{2} \mathrm{PO}_{4}$ (T3), $\mathrm{KI}$ (T4), $\mathrm{KCl}$ (T5), $\mathrm{NaCl}$ (T6), $\left(\mathrm{NH}_{4}\right)_{2} \mathrm{SO}_{4}$ (T7), $\mathrm{Na}_{2} \mathrm{SO}_{4}$ (T8), $\mathrm{Na}_{2} \mathrm{HPO}_{4}$ (T9), $\mathrm{Ca}\left(\mathrm{NO}_{3}\right)_{2}$ (T10), $\mathrm{Mg}\left(\mathrm{NO}_{3}\right)_{2}$ (T11). Pots with topsoil were arranged in a randomized complete block design. Eight seeds were planted in each pot.

\subsection{Treatment and Statistical Analysis}

The plants were treated with $300 \mathrm{~mL}$ of Hoagland solution and $300 \mathrm{~mL}$ of distilled water. This was to initiate germination and have healthy plants before chemical treatments. The plants germinated in ten days. Then pots were watered once a week. The temperature in the greenhouse throughout this experiment varied from $32.2^{\circ} \mathrm{C}$ to $35^{\circ} \mathrm{C}$. The treatment included $30 \mathrm{mmol}$ of chemicals application/pot at V3 stage to all 11 groups, while the control received the same amount of water. After 10 days of chemical treatments, leaves were sampled and dried in oven for $48-72$ hours at $65^{\circ} \mathrm{C}$. 2.0 grams of dry ground leaf samples were sent to Soil, Plant and Water testing laboratory, UGA, Athens, GA, for mineral analysis. Nutrients were analyzed by digesting $0.5 \mathrm{~g}$ of samples in a microwave digestion system. Briefly, dried samples were ground in a Wiley mill and passed through a 20 mesh screen. The samples were digested following EPA Method 3052 [15] as follows: $0.500 \mathrm{~g}$ samples were weighed out and placed in fluorocarbon polymer microwave vessels, $10 \mathrm{~mL}$ concentrated $\mathrm{HNO}_{3}$ was added to each vessel. Vessels were sealed and placed in a microwave digester (CEM Mars 6 Microwave, Matthews, NC, USA) and heated at $200^{\circ} \mathrm{C}$ for 30 minutes. The digests (solutions) were transferred quantitatively into volumetric flasks and brought to $100 \mathrm{~mL}$ volume with deionized water. Finally, the solutions were analyzed for various elements ( $\mathrm{P}, \mathrm{K}, \mathrm{S}, \mathrm{Ca}, \mathrm{Mg}, \mathrm{Fe}, \mathrm{Mn}, \mathrm{Al}, \mathrm{B}, \mathrm{Cu}, \mathrm{Zn}, \mathrm{Ni}$ ) following EPA Method 200.8 [16] by Inductively Coupled Plasma-Optical Emis- 
sion Spectroscopy (ICP-OES). Means were separated using Fisher's Least Significant Difference test using $5 \%$ as level of significance.

\section{Results}

\section{Leaf Mineral Composition}

Results from leaf mineral analysis are illustrated in detail in Table 1, which contains mineral concentration, mean, and statistical significance compared to control treatments. According to our leaf mineral analysis, $\mathrm{K}$ concentration increased by $10 \%$ or more in the following treatments, T1, T2, T4, T5, T10 and $\mathrm{T} 11$, the highest increase found in $\mathrm{T} 4$ by $31.9 \%$. $\mathrm{P}$ concentration increased in $\mathrm{T} 3$, $\mathrm{T} 4$ and $\mathrm{T} 9$, the highest increase again in T4 $(60.8 \%)$, while Ca had increased only by two treatments $\mathrm{T} 8$ and $\mathrm{T} 10$ by $20 \%$. Sulfur, another macronutrient showed an increase in the leaves by T2, T4 and T7. Among the micronutrients, B concentration was increased by several treatments (T1, T3, T4, T5, T6, T7 and T9), the highest increase observed in $\mathrm{T} 3$ and $\mathrm{T} 4$, which was $43.47 \%$ and $53.6 \%$ respectively. $\mathrm{Cu}$ concentration increased by $\mathrm{T} 1, \mathrm{~T} 4$ and $\mathrm{T} 10$, the highest reported in $\mathrm{T} 4$ (36.3\%). $\mathrm{Zn}$ adsorption also increased in T2, T4 and T7, while Fe increase was observed only in one treatment T8. Overall, several treatments (T1, T2, $\mathrm{T} 4$, T5, T8 and T10) increased $\mathrm{K}$ concentration in leaves, several treatments (T1, T2, T3, T4, T5, T7, and T9) increased B (Table 2). Out of all the above treatments, the four treatments $\mathrm{T} 1, \mathrm{~T} 2, \mathrm{~T} 4$ and $\mathrm{T} 5$ proved to be the most efficient in both $\mathrm{K}$ and B uptake. KI (T4) had the most positive outlook in acquisition of several mineral nutrients $(\mathrm{Ca}, \mathrm{K}, \mathrm{Mg}, \mathrm{B}, \mathrm{Cu}$ and $\mathrm{Zn}$ ) by the plants (Table 2).

\section{Discussion}

\subsection{Comparing Anion Effects}

a) Comparing $\mathrm{T} 1\left(\mathrm{KNO}_{3}\right)$ to $\mathrm{T} 4(\mathrm{KI})$ Treatment: $\mathrm{I}^{1-}$ to $\mathrm{NO}_{3}^{1-}$

Iodine is not considered as an essential element for land plants, however, KI treatment in our study shows iodine to have beneficial effect on uptake of several minerals in the leaves for example $\mathrm{K}, \mathrm{Mg}, \mathrm{P}, \mathrm{S}, \mathrm{B}, \mathrm{Cu}$ and $\mathrm{Zn}$ by $32.0 \%, 8.0 \%$, $61.0 \%, 38.0 \%, 53.6 \%, 36.3 \%$ respectively compared to control, which was similar to the findings reported in other studies [12] [17]. While comparing the two treatments $\mathrm{T} 1$ vs $\mathrm{T} 4, \mathrm{~T} 1$ increased $\mathrm{K}, \mathrm{B}, \mathrm{Cu}$ concentration in the leaves by $11.9 \%$, $23.0 \%$ and $11.5 \%$, but iodine anion impacted more positively by increasing uptake and accumulation of several other minerals in the leaves as listed above. Iodine has been studied to have significant impact on the redox state of the system that absorbs the element, therefore, it interacts with other chemical components of the system, such as organic compounds and metal ions, modifying the oxidation state and bioavailability [18] [19]. The results from our experiments showed synergistic effect on other elements as evidenced by their increased accumulation in the soybean leaves. However, results widely vary in different plant 
Table 1. Mean values of macro and micronutrients, and significant differences of treatments with respect to control.

\begin{tabular}{|c|c|c|c|c|c|c|c|c|c|c|c|}
\hline \multirow[b]{2}{*}{ Treatments } & \multicolumn{5}{|c|}{ Macronutrients (\%) } & \multicolumn{6}{|c|}{ Trace elements (Micronutrients) (mg/kg) } \\
\hline & $\mathrm{Ca}$ & K & $\mathrm{Mg}$ & $\mathrm{P}$ & S & B & $\mathrm{Cu}$ & $\mathrm{Fe}$ & Mn & $\mathrm{Zn}$ & $\mathrm{Na}$ \\
\hline Control & $0.64 \mathrm{BCD}$ & $4.26 \mathrm{E}$ & $0.49 \mathrm{~B}$ & $0.23 \mathrm{CDE}$ & $0.31 \mathrm{DE}$ & $71.26 \mathrm{~F}$ & $6.97 \mathrm{C}$ & $70.67 \mathrm{~B}$ & $596.5 \mathrm{BCD}$ & $134.60 \mathrm{~F}$ & 299.63 BC \\
\hline $\mathrm{T} 1-\mathrm{KNO}_{3}$ & $\begin{array}{l}0.51 \mathrm{~F} \\
(-10 \%)\end{array}$ & $\begin{array}{l}4.77 \mathrm{BC} \\
(11.9 \%)\end{array}$ & $0.47 \mathrm{BCD}$ & $0.22 \mathrm{DE}$ & $0.30 \mathrm{DEF}$ & $\begin{array}{c}87.70 \mathrm{BC} \\
(23 \%)\end{array}$ & $\begin{array}{c}7.77 \mathrm{~B} \\
(11.5 \%)\end{array}$ & $76.27 \mathrm{~B}$ & $525.9 \mathrm{D}$ & $140.87 \mathrm{DEF}$ & $\begin{array}{c}210.3 \mathrm{G} \\
(-29.81 \%)\end{array}$ \\
\hline $\mathrm{T} 2-\mathrm{NH}_{4} \mathrm{NO}_{3}$ & $0.64 \mathrm{~B}$ & $\begin{array}{c}4.87 \mathrm{~B} \\
(14.0 \%)\end{array}$ & $0.49 \mathrm{~B}$ & $0.24 \mathrm{C}$ & $\begin{array}{c}0.39 \mathrm{C} \\
(26.0 \%)\end{array}$ & $90.75 \mathrm{~B}$ & $6.75 \mathrm{CD}$ & $76.40 \mathrm{~B}$ & $549.7 \mathrm{D}$ & $\begin{array}{c}156.50 \mathrm{~B} \\
(16.2 \%)\end{array}$ & $\begin{array}{c}233.10 \mathrm{EFG} \\
(-22.0 \%)\end{array}$ \\
\hline T3- $\left(\mathrm{NH}_{4}\right) \mathrm{H}_{2} \mathrm{PO}_{4}$ & $0.58 \mathrm{CE}$ & $4.39 \mathrm{E}$ & $0.48 \mathrm{BCD}$ & $\begin{array}{c}0.33 \mathrm{~B} \\
(43.47 \%)\end{array}$ & $0.31 \mathrm{DEF}$ & $\begin{array}{c}104.03 \mathrm{~A} \\
(46 \%)\end{array}$ & $6.83 \mathrm{C}$ & $67.77 \mathrm{~B}$ & $581.0 \mathrm{BCD}$ & $\begin{array}{c}145.63 \mathrm{CD} \\
(8 \%)\end{array}$ & $\begin{array}{c}218.63 \mathrm{FG} \\
(-27.2 \%)\end{array}$ \\
\hline T4-KI & $0.57 \mathrm{DEF}$ & $\begin{array}{c}5.62 \mathrm{~A} \\
(31.9 \%)\end{array}$ & $0.53 \mathrm{~A}(8 \%)$ & $\begin{array}{c}0.37 \mathrm{~A} \\
(60.8 \%)\end{array}$ & $\begin{array}{c}0.43 \text { B } \\
(38.7 \%)\end{array}$ & $\begin{array}{l}109.50 \mathrm{~A} \\
(53.6 \%)\end{array}$ & $\begin{array}{c}9.50 \mathrm{~A} \\
(36.3 \%)\end{array}$ & $92.40 \mathrm{~B}$ & $\begin{array}{c}388.5 \mathrm{E} \\
(-34.9 \%)\end{array}$ & $\begin{array}{c}149.20 \mathrm{BC} \\
(10.8 \%)\end{array}$ & $\begin{array}{c}465.2 \mathrm{~A} \\
(55.25 \%)\end{array}$ \\
\hline $\mathrm{T} 5-\mathrm{KCl}$ & $0.65 \mathrm{BC}$ & $\begin{array}{c}4.72 \mathrm{C} \\
(10.8 \%)\end{array}$ & $0.48 \mathrm{BC}$ & $0.22 \mathrm{DE}$ & $\begin{array}{c}0.24 \mathrm{G} \\
(-22.6 \%)\end{array}$ & $\begin{array}{c}82.73 \mathrm{CD} \\
(15.9 \%)\end{array}$ & $6.53 \mathrm{CD}$ & $71.80 \mathrm{~B}$ & $565.0 \mathrm{CD}$ & $138.50 \mathrm{DEF}$ & $\begin{array}{c}255.43 \mathrm{DEF} \\
(-14.75 \%)\end{array}$ \\
\hline T6- $\mathrm{NaCl}$ & $0.61 \mathrm{CDE}$ & $4.56 \mathrm{D}(7 \%)$ & $\begin{array}{c}0.46 \mathrm{CDE} \\
(-6.1 \%)\end{array}$ & $0.23 \mathrm{CDE}$ & $\begin{array}{c}0.27 \text { FG } \\
(-12.9 \%)\end{array}$ & $\begin{array}{c}79.67 \mathrm{DE} \\
(11.7 \%)\end{array}$ & $6.80 \mathrm{C}$ & $83.53 \mathrm{~B}$ & $559.4 \mathrm{CD}$ & $140.90 \mathrm{DEF}$ & $\begin{array}{l}256.90 \\
\text { CDEF }\end{array}$ \\
\hline $\mathrm{T} 7-\left(\mathrm{NH}_{4}\right)_{2} \mathrm{SO}_{4}$ & $0.68 \mathrm{~B}$ & $4.0 \mathrm{~F}(-6.1)$ & $0.47 \mathrm{BCDE}$ & $0.24 \mathrm{CD}$ & $\begin{array}{c}0.52 \mathrm{~A} \\
(67.8 \%)\end{array}$ & $\begin{array}{c}79.13 \mathrm{DE} \\
(11 \%)\end{array}$ & $\begin{array}{l}6.23 \mathrm{D} \\
(-11 \%)\end{array}$ & $104.50 \mathrm{~B}$ & $614.1 \mathrm{BC}$ & $\begin{array}{l}167.40 \mathrm{~A} \\
(24.4 \%)\end{array}$ & $295.70 \mathrm{BCD}$ \\
\hline $\mathrm{T} 8-\mathrm{Na}_{2} \mathrm{SO}_{4}$ & $\begin{array}{c}0.77 \mathrm{~A} \\
(20.3 \%)\end{array}$ & $\begin{array}{l}4.54 \mathrm{D} \\
(5.6 \%)\end{array}$ & $0.48 \mathrm{BCD}$ & $0.22 \mathrm{CDE}$ & $0.33 \mathrm{D}$ & $71.36 \mathrm{~F}$ & $6.83 \mathrm{C}$ & $\begin{array}{c}197.00 \mathrm{~A} \\
(179 \%)\end{array}$ & $555.6 \mathrm{CD}$ & $138.83 \mathrm{DEF}$ & $272.57 \mathrm{CDE}$ \\
\hline $\mathrm{T} 9-\mathrm{Na}_{2}(\mathrm{HPO})_{4}$ & $0.61 \mathrm{BCE}$ & $4.35 \mathrm{E}$ & $\begin{array}{c}0.45 \mathrm{E} \\
(-8.2 \%)\end{array}$ & $\begin{array}{c}0.32 \text { B } \\
(39.13 \%)\end{array}$ & $0.29 \mathrm{EF}$ & $\begin{array}{c}77.80 \mathrm{DE} \\
(9 \%)\end{array}$ & $6.47 \mathrm{CD}$ & $79.20 \mathrm{~B}$ & $648.4 \mathrm{~B}$ & $143.23 \mathrm{CDE}$ & $\begin{array}{c}219.53 \mathrm{FG} \\
(-26.7 \%)\end{array}$ \\
\hline $\mathrm{T} 10-\mathrm{Ca}\left(\mathrm{NO}_{3}\right)_{2}$ & $\begin{array}{l}0.81 \mathrm{~A} \\
(20 \%)\end{array}$ & $\begin{array}{l}4.76 \mathrm{BC} \\
(11.7 \%)\end{array}$ & $\begin{array}{c}0.54 \mathrm{~A} \\
(10.2 \%)\end{array}$ & $\begin{array}{c}0.20 \mathrm{E} \\
(-13.0 \%)\end{array}$ & $\begin{array}{c}0.27 \mathrm{FG} \\
(-12.9 \%)\end{array}$ & $76.13 \mathrm{EF}$ & $\begin{array}{c}5.50 \mathrm{E} \\
(14.3 \%)\end{array}$ & $76.67 \mathrm{~B}$ & $\begin{array}{l}726.3 \mathrm{~A} \\
(21.8 \%)\end{array}$ & $135.00 \mathrm{~F}$ & $\begin{array}{c}189.47 \mathrm{G} \\
(-36.77 \%)\end{array}$ \\
\hline $\mathrm{T} 11-\mathrm{Mg}\left(\mathrm{NO}_{3}\right)_{2}$ & $\begin{array}{l}0.56 \mathrm{EF} \\
(-12 \%)\end{array}$ & $\begin{array}{l}4.75 \mathrm{BC} \\
(11.5 \%)\end{array}$ & $\begin{array}{l}0.46 \mathrm{DE} \\
(-6.1 \%)\end{array}$ & $\begin{array}{c}0.21 \mathrm{E} \\
(-8.7 \%)\end{array}$ & $0.33 \mathrm{D}$ & $74.93 \mathrm{EF}$ & $6.63 \mathrm{CD}$ & $71.90 \mathrm{~B}$ & $\begin{array}{c}400.6 \mathrm{E} \\
(-32.8 \%)\end{array}$ & $135.63 \mathrm{EF}$ & 321.93 B \\
\hline
\end{tabular}

Notes: Means given within a column bearing the same letter as the control are not significantly different at $p<0.05$. The numbers in the brackets with $\%$ are the percentage changes increase or decrease in seed composition.

species and often have inconsistent result [20] [21]. Further, plants can accumulate iodine in the leaves but this effect does not necessarily translate into fruits and vegetables. The agricultural application of iodine is not fully studied as very little study exists, however, since few studies undertaken have shown promising role of iodine in enhancement of plant growth, antioxidant capacity and increased stress tolerance, hence, there is a critical need to expand research in the area of iodine biofortification. The concentration of the KI treatment used in our study although increased the uptake of several minerals (Table 2) in the leaves but eventually caused toxicity to the plants in which most plants died soon after the leaf sampling, similarly, as evidenced by other studies [11]. The toxicity could be due to volatilization of iodine and changes in the mineral composition of plants due to redox phenomenon [19].

b) Comparing $\mathrm{T} 1\left(\mathrm{KNO}_{3}\right)$ to $\mathrm{T} 5(\mathrm{KCl})$ Treatment: $\mathrm{NO}_{3}^{1-}$ to $\mathrm{Cl}^{1-}$

$\mathrm{T} 1$ increased $\mathrm{K}, \mathrm{B}, \mathrm{Cu}$, in the leaves by $11.9 \%, 23.0 \%$ and $11.5 \%$ and decreased $\mathrm{Ca}$ and $\mathrm{Na}$ by $10.0 \%$ and $29.8 \%$ respectively, which is consistent with other studies [16] which demonstrates nutrient cation exchange is possible up to a certain concentration without causing any injury to the plants. Earlier studies [22] have 
Table 2. Overall effect of the application of each treatment according to the significant differences.

\begin{tabular}{|c|c|c|}
\hline Chemical Treatment & Main Results & Main Nutrients Affected \\
\hline $\mathrm{KNO}_{3}$ & + & $\mathrm{K}, \mathrm{B}, \mathrm{Cu}$ \\
\hline $\mathrm{KNO}_{3}$ & - & $\mathrm{Ca}, \mathrm{Na}$ \\
\hline $\mathrm{NH}_{4} \mathrm{NO}_{3}$ & + & $\mathrm{K}, \mathrm{S}, \mathrm{Zn}$ \\
\hline $\mathrm{NH}_{4} \mathrm{NO}_{3}$ & - & $\mathrm{Na}$ \\
\hline$\left(\mathrm{NH}_{4}\right) \mathrm{HPO}_{4}$ & + & $\mathrm{P}, \mathrm{B}, \mathrm{Zn}$ \\
\hline$\left(\mathrm{NH}_{4}\right) \mathrm{HPO}_{4}$ & - & $\mathrm{Na}$ \\
\hline $\mathrm{KI}$ & + & $\mathrm{K}, \mathrm{Mg}, \mathrm{P}, \mathrm{S}, \mathrm{B}, \mathrm{Cu}, \mathrm{Zn}, \mathrm{Na}$ \\
\hline $\mathrm{KI}$ & - & $\mathrm{Mn}$ \\
\hline $\mathrm{KCl}$ & + & $\mathrm{K}, \mathrm{B}$ \\
\hline $\mathrm{KCl}$ & - & $\mathrm{S}, \mathrm{Na}$ \\
\hline $\mathrm{NaCl}$ & + & $\mathrm{K}, \mathrm{B}$ \\
\hline $\mathrm{NaCl}$ & - & $\mathrm{Mg}, \mathrm{S}$ \\
\hline$\left(\mathrm{NH}_{4}\right)_{2} \mathrm{SO}_{4}$ & + & $\mathrm{S}, \mathrm{B}, \mathrm{Zn}$ \\
\hline$\left(\mathrm{NH}_{4}\right)_{2} \mathrm{SO}_{4}$ & - & $\mathrm{K}, \mathrm{Cu}$ \\
\hline $\mathrm{Na}_{2} \mathrm{SO}_{4}$ & + & $\mathrm{Ca}, \mathrm{K}, \mathrm{Fe}$ \\
\hline $\mathrm{Na}_{2}(\mathrm{HPO})_{4}$ & + & $\mathrm{P}, \mathrm{B}$ \\
\hline $\mathrm{Na}_{2}(\mathrm{HPO})_{4}$ & - & $\mathrm{Mg}, \mathrm{Na}$ \\
\hline $\mathrm{Ca}\left(\mathrm{NO}_{3}\right)_{2}$ & + & $\mathrm{Ca}, \mathrm{K} \mathrm{Mg}, \mathrm{Cu}, \mathrm{Mn}$ \\
\hline $\mathrm{Ca}\left(\mathrm{NO}_{3}\right)_{2}$ & - & $\mathrm{P}, \mathrm{S}, \mathrm{Na}$ \\
\hline $\mathrm{Mg}\left(\mathrm{NO}_{3}\right)_{2}$ & + & $\mathrm{K}$ \\
\hline $\mathrm{Mg}\left(\mathrm{NO}_{3}\right)_{2}$ & - & $\mathrm{Ca}, \mathrm{Mg}, \mathrm{P}, \mathrm{Mn}$ \\
\hline
\end{tabular}

Main Results: (+), positive; (-), negative.

also reported that the plants tend to be healthier where $\mathrm{KNO}_{3}$ is the source for $\mathrm{K}$ compared to $\mathrm{KCl}$. T5 treatment increased $\mathrm{K}$ and B by $10.8 \%$ and $15.9 \%$ respectively and decreased $\mathrm{S}$ and $\mathrm{Na}$ by $22.6 \%$ and $14.8 \%$ respectively. Both treatments $\mathrm{NO}_{3}^{1-}$ and $\mathrm{Cl}^{1-}$ increase $\mathrm{K}, \mathrm{B}$ while both decreasing Na. Previous studies have shown similar results, when $\mathrm{Cl}$ is applied to soils in $\mathrm{KCl}$ form, it tends to substitute for N, S, P in plants resulting in lower protein content [23]. Hence, $\mathrm{KCl}$ will not be a good treatment where plants are grown for protein value for example soybean.

c) Comparing T2 $\left(\mathrm{NH}_{4} \mathrm{NO}_{3}\right)$ to T3 $\left(\left(\mathrm{NH}_{4}\right) \mathrm{H}_{2} \mathrm{PO}_{4}\right)$ Treatment: $\mathrm{NO}_{3}^{1-}$ to $\mathrm{H}_{2} \mathrm{PO}_{4}^{1-}$

T2 treatment increased K, S, B, Zn by $14.0 \%, 26.0 \%, 27.3 \%$ and $16.0 \%$ respectively while decreasing Na by $22.0 \%$. T3 increased P, B, Zn by $43.5 \%, 46.0 \%$ and $8.0 \%$ respectively and decreased $\mathrm{Na}$ by $27.0 \%$. Common in both are $\mathrm{B}$ and $\mathrm{Zn}$. $\mathrm{H}_{2} \mathrm{PO}_{4}^{1-}$ increased $\mathrm{P}$ by $43.5 \%$ and $\mathrm{S}$ by $46.0 \%$. In comparison, ammonium nitrate is better suited to controlling acidic soil, however, application of ammo- 
nium phosphate with the two basic components of the fertilizer upon dissolution will separate to release ammonium $\left(\mathrm{NH}_{4}^{1+}\right)$ and phosphate $\left(\mathrm{H}_{2} \mathrm{PO}_{4}^{1-}\right)$, both of which plants rely on for healthy, sustained growth [24]. Both treatments had positive effect on mineral uptake, however, will depend on the soil mineral test and crop preference.

d) Comparing $\mathrm{T} 8\left(\mathrm{Na}_{2} \mathrm{SO}_{4}\right)$ to $\mathrm{T} 9\left(\mathrm{Na}_{2}(\mathrm{HPO})_{4}\right)$ Treatment: $\mathrm{SO}_{4}^{2-}$ to $\mathrm{HPO}_{4}^{2-}$

$\mathrm{T} 8$ increased $\mathrm{Ca}, \mathrm{K}$, and $\mathrm{Fe}$ by $20.3 \%, 5.6 \%$ and $179.0 \%$ respectively, while $\mathrm{T} 9$ treatment increased $\mathrm{P}$ and B by $39.1 \%$ and $9.0 \%$ respectively and decreased $\mathrm{Mg}$ and $\mathrm{Na}$ by $8.2 \%$ and $26.7 \%$ respectively. In comparison, $\mathrm{Na}_{2} \mathrm{SO}_{4}$ offers significant increase in Fe. Though Na (T8 and T9) is considered as beneficial element by some agricultural crops [25] and as evidenced in the present study $\mathrm{Na}_{2} \mathrm{SO}_{4}$ (T8) application considerably increased the transport and uptake of $\mathrm{Fe}$ into the plants, however, there is need to further study the concentration of the chemical applied more carefully since higher dosage might cause plant injury

\subsection{Comparing Cation Effects}

a) Comparing $\mathrm{T} 1\left(\mathrm{KNO}_{3}\right)$ to $\mathrm{T} 2\left(\mathrm{NH}_{4} \mathrm{NO}_{3}\right)$ Treatment: $\mathrm{K}^{1+}$ to $\mathrm{NH}_{4}^{1+}$

T1treatment increased $\mathrm{K}, \mathrm{B}, \mathrm{Cu}$, in the leaves by $11.9 \%, 23.0 \%$ and $11.5 \%$ increased respectively, while decreasing $\mathrm{Ca}$ and $\mathrm{Na}$ by $10.0 \%$ and $29.8 \%$ respectively. T2 treatment increased K, S, B, Zn by $14.0 \%, 26.0 \%, 27.3 \%$ and $16.0 \%$ respectively and decreased $\mathrm{Na}$ by $22.0 \%$. However, $\mathrm{KNO}_{3}$ is a soluble source of two major essential plant nutrients, commonly used of high value crops that could benefit from nitrate $\left(\mathrm{NO}_{3}\right)$ and a source of potassium $(\mathrm{K})$ free of chloride [26]. Ammonium $\left(\mathrm{NH}_{4}\right)$ is again a cation which competes with other cations like potassium, calcium and magnesium which may cause $\mathrm{Ca}$ and $\mathrm{Mg}$ deficiency at high concentrations [27]. Hence, it is important to test the capacity of plant species to utilize ammonium at acidic as well as near neutral $\mathrm{pH}$ to dissociate ammonium and $\mathrm{pH}$ effects. However, the concentrations used in our present study had similar positive effect in increasing $\mathrm{K}, \mathrm{B}$ while significantly decreasing $\mathrm{Na}$.

b) Comparing $\mathrm{T} 5(\mathrm{KCl})$ to $\mathrm{T} 6(\mathrm{NaCl})$ Treatment, $\mathrm{K}^{1+}$ to $\mathrm{Na}^{1+}$

T5 treatments increased $\mathrm{K}$ and $\mathrm{B}$ by $10.8 \%$ and $15.9 \%$ respectively and decreased $\mathrm{S}$ and $\mathrm{Na}$ by $22.6 \%$ and $14.8 \%$ respectively. T6 treatment increased $\mathrm{K}$ and $\mathrm{B}$ by $7.0 \%$ and $11.8 \%$ respectively while decreasing $\mathrm{Mg}$ and $\mathrm{S}$ by 6.1 and $12.9 \%$ respectively. It seems both cations $\left(\mathrm{K}^{1+} \mathrm{vs} \mathrm{Na}^{1+}\right)$ increase $\mathrm{K}$ and $\mathrm{B}$, however $\mathrm{KCl}$ treatment decreased $\mathrm{S}$ and $\mathrm{Na}$, and $\mathrm{NaCl}$ decreased $\mathrm{S}$ and $\mathrm{Mg}$, As studied earlier, when $\mathrm{Cl}$ is applied to soils in $\mathrm{KCl}$, it tends to substitute for $\mathrm{N}+\mathrm{S}+\mathrm{P}$ in the plants growing on the soil and lower their protein content [23]. High $\mathrm{Cl}$ concentrations reduce the photosynthetic capacity due to chlorophyll degradation [28]. Furthermore, sulfur being an important constituent of protein and magnesium having an important role in chlorophyll production, the two treatments do not offer positive outcome.

c) Comparing $\mathrm{T} 10\left(\mathrm{Ca}\left(\mathrm{NO}_{3}\right)_{2}\right)$ to $\mathrm{T} 11\left(\mathrm{Mg}\left(\mathrm{NO}_{3}\right)_{2}\right)$ Treatment: $\mathrm{Ca}^{2+}$ to $\mathrm{Mg}^{2+}$

T10 treatment increased $\mathrm{Ca}, \mathrm{K}, \mathrm{Mg}, \mathrm{P}, \mathrm{Cu}$, and $\mathrm{Mn}$ by $20.0 \%, 11.7 \%, 10.2 \%$, 
$13.0 \%, 14.3 \%$ and $21.8 \%$ respectively and decreased $\mathrm{S}$ and $\mathrm{Na}$ by $12.9 \%$ and $36.8 \%$ respectively. Similarly, previous studies have reported an increase in $\mathrm{K}$ content while decreasing $\mathrm{Na}$ in plants in the presence of supplemental $\mathrm{Ca}$, which is in part due to $\mathrm{Ca}, \mathrm{K}$ and $\mathrm{Mg}$ which are known to be involved in cation exchange. T11 treatment, similarly, increased $\mathrm{Ca}, \mathrm{K}, \mathrm{P}$, but in contrast to T10, increased $\mathrm{Na}$ by $7.4 \%$, while decreasing $\mathrm{Mg}$ and $\mathrm{Mn}$ by $6.1 \%$ and $32.8 \%$ respectively. Although Both $\mathrm{Ca}^{2+}$ and $\mathrm{Mg}^{2+}$ had a positive role in increasing $\mathrm{Ca}, \mathrm{K}$, and $\mathrm{P}$ in leaves, in comparison, T10 increased several other minerals like $\mathrm{Mg}, \mathrm{Cu}$ and Mn, hence, T10 with additional benefits and at the same time less expensive to treat could be the mineral of choice in many instances depending upon mineral nutrient index in the soil [29] [30].

\section{Conclusion}

In comparison, $\mathrm{T} 1\left(\mathrm{KNO}_{3}\right), \mathrm{T} 2\left(\mathrm{NH}_{4} \mathrm{NO}_{3}\right)$, $\mathrm{T} 4(\mathrm{KI})$ and $\mathrm{T} 5(\mathrm{KCl})$ treatments were most effective in increasing $\mathrm{K}$ and $\mathrm{B}$ both. Iodine is not considered as an essential element for land plants; however, KI treatment (T4) in our study shows iodine to have very promising effect on uptake of several minerals in the leaves like $\mathrm{K}, \mathrm{Mg}, \mathrm{P}, \mathrm{S}, \mathrm{B}, \mathrm{Cu}$ and $\mathrm{Zn}$. Another chemical was $\mathrm{Ca}\left(\mathrm{NO}_{3}\right)$ which offered positive results in the uptake of number of minerals like $\mathrm{Mg}, \mathrm{Cu}$ and $\mathrm{Mn}$. Both $\mathrm{Ca}^{2+}$ and $\mathrm{Mg}^{2+}$ have a role in increasing $\mathrm{Ca}, \mathrm{K}$, and $\mathrm{P}$ in leaves. Although every treatment had an impact in increasing one or two of the essential nutrient elements required by the plants, we concluded the three treatment groups $\mathrm{T} 1$ $\left(\mathrm{KNO}_{3}\right), \mathrm{T} 4(\mathrm{KI})$ and $\mathrm{T} 10 \mathrm{Ca}\left(\mathrm{NO}_{3}\right)_{2}$ to be the most efficient treatments among all applications in increasing several minerals in soybean leaves (Table 2). The choice of treating the crops will ultimately depend on crop preference, soil $\mathrm{pH}$, and nutrient deficiency.

\section{Acknowledgements}

The authors would like to thank Dr. Nacer Bellaloui, USDA-ARS, Stoneville, MS, USA, for his technical assistance for this project and for reviewing the manuscript. Also, they are thankful to Sandra Mosley for her technical assistance. This study in part was supported by MSEIP grant (STEM Changers) from Department of Education, at Mississippi Valley State University.

\section{Conflicts of Interest}

The authors declare no conflicts of interest regarding the publication of this paper.

\section{References}

[1] Ash, M., Livezey, J. and Dohlman, E. (2006) Soybean Backgrounder. Electronic Outlook Report from the Economic Research Service, USDA. https://www.ers.usda.gov/webdocs/publications/38482/29495_ocs200601.pdf?v $=0$

[2] Wilson, R.F. (2008) Soybean: Market Driven Research Needs. In: Stacey, G., Ed., 
Genetics and Genomics of Soybean, Plant Genetics and Genomics. Crops and Models, Vol. 2, Springer, New York, 3-15. https://doi.org/10.1007/978-0-387-72299-3_1

[3] Parikh, S.J. and James, B.R. (2012) Soil: The Foundation of Agriculture. Nature Education Knowledge, 3, 2.

http://www.nature.com/scitable/knowledge/library/soil-the-foundation-of-agricultu re-84224268

[4] Smith, D. (2010) Micronutrients Can Have a Macro Impact. Farm Journal, 134, 27-30.

[5] Yasari, E. and Vahedi, A. (2012) Micronutrients Impact on Soybean (Glycine max (Merrill)) Qualitative and Quantitative Traits. International Journal of Biology, 4, 112-118. https://doi.org/10.5539/ijb.v4n2p112

[6] Martens, D.C. and Westermann, D.T. (1991) Fertilizer Applications for Correcting Micronutrient Deficiencies. In: Micronutrients in Agriculture, 2nd Edition, SSSA Book Series, No. 4, SSSA, Madison, 549-592.

http://eprints.nwisrl.ars.usda.gov/777/1/753.pdf https://doi.org/10.2136/sssabookser4.2ed.c15

[7] Vahedi, A. (2012) The Appraisal of Micronutrient Impact on Absorption of Macroand Micro-Nutrients in Tellar Cultivar of Soybean. International Journal of Biology, 4, 120-128. https://doi.org/10.5539/ijb.v4n1p120

[8] Bouis, H.E. and Saltzman, A. (2017) Improving Nutrition through Biofortification: A Review of Evidence from Harvest Plus, 2003 through 2016.

[9] Bilski, J., Jacob, D., Soumaila, F., Kraft, C. and Farnsworth, A. (2012) Agronomic Biofortification of Cereal Crop Plants with Fe, Zn, and Se, by the Utilization of Coal Fly Ash as Plant Growth Media. Advances in Bioresearch, 3, 130-136.

[10] Wakeel, A., Farooq, M., Bashir, K. and Ozturk, L. (2018) Micronutrient Malnutrition and Biofortification: Recent Advances and Future Perspectives. In: Plant Micronutrient Use Efficiency, 2018 Molecular and Genomic Perspectives in Crop Plants, Elsevier, Amsterdam, 225-243. https://doi.org/10.1016/B978-0-12-812104-7.00017-4

[11] Umaly, C.R. and Poel, W.L. (1970) Effects of Various Concentrations of Iodine as Potassium Iodide on the Growth of Barley, Tomato and Pea in Nutrient Solution Culture. Annals of Botany, 34, 919-926. https://doi.org/10.1093/oxfordjournals.aob.a084423

[12] Medrano-Marcias, J., Liija Martinez, P., Gonzales-Morales, S., Juarez-Meldonado, A. and Benavides-Menoza, A. (2016) Use of Iodine to Biofortify and Promote Growth and Stress Tolerance in Crops. Frontiers in Plant Science, 7, Article 1146.

[13] Medrano-Macías, J., et al. (2016) Use of Iodine to Biofortify and Promote Growth and Stress Tolerance in Crops. Frontiers in Plant Science, 7, 1146. https://doi.org/10.3389/fpls.2016.01146

[14] Goli, M.B., Manju, P., Daniel, K., Bellaloui, N. and De Wra-chien, D. (2018) The Role of Metal Ions in Protein and Fatty Acids Biosynthesis in Soybean under Micronutrients Application to Soil. Agricultural Sciences, 9, 741-749. https://doi.org/10.4236/as.2018.96052

[15] USEPA (1995) Microwave Assisted Acid Digestion of Siliceous and Organically Based Matrices, Method 3052. 3rd Edition, Test Methods for Evaluating Solid Waste. US Environmental Protection Agency, Washington DC.

[16] Creed, J.T., Brockhoff, C.A. and Martin, T.D. (1994) US-EPA Method 200.8: Determination of Trace Elements in Waters and Wastes by Inductively Coupled Plas- 
ma-Mass Spectrometry. Environmental Monitoring Systems Laboratory Office of Research and Development, Revision 5.4 EMMC Version, U.S. Environmental Protection Agency, Cincinnati.

[17] Smoleń, S., Kowalska, I. and Sady, W. (2014) Assessment of Biofortification with Iodine and Selenium of Lettuce Cultivated in the NFT Hydroponic System. Scientia Horticulturae, 166, 9-16. https://doi.org/10.1016/j.scienta.2013.11.011

[18] Venturi, S. (2011) Evolutionary Significance of Iodine. Current Chemical Biology, 5, 155-162. https://doi.org/10.2174/187231311796765012

[19] Hageman, R.H., Hodge, E.S. and McHargue, J.S. (1942) Effect of Potassium Iodide on the Ascorbic Acid Content and Growth of Tomato Plants. Plant Physiology, 17, 465-472. https://doi.org/10.1104/pp.17.3.465

[20] Landini, M., Gonzali, S. and Perata, P. (2011) Iodine Biofortification in Tomato. Journal of Plant Nutrition and Soil Science, 174, 480-486. https://doi.org/10.1002/jpln.201000395

[21] Landini, M., Gonzali, S., Kiferle, C., Tonacchera, M., Agretti, P., Dimida, A., et al. (2012) Metabolic Engineering of the Iodine Content in Arabidopsis. Scientific Reports, 2, Article No. 338. https://doi.org/10.1038/srep00338

[22] Oosthuyse, S.A. (2013) Potassium Input, Either as $\mathrm{KNO}_{3}, \mathrm{~K}_{2} \mathrm{SO}_{4}$ or $\mathrm{KCL}$, on Growth and Yield of Sand-Potted Tomato Plants Grown in Saline Conditions. ISHS Acta Horticulturae, 984, 275-284. https://doi.org/10.17660/ActaHortic.2013.984.32

[23] Bear, F.E. (1950) Cation and Anion Relationship in Plants and Their Bearing on Crop Quality. Agronomy Journal, 42, 176-178. https://doi.org/10.2134/agronj1950.00021962004200040002x

[24] Monoammonium Phosphate: Mosaic Crop Nutrition. Monoammonium Phosphate, Mosaic Crop Nutrition, Nutrient Source Specifics (No. 9), International Plant Nutrition Institute. http://www.cropnutrition.com/monoammonium-phosphate

[25] Kaur, S., Kaur, N., Siddique, K.H.M. and Nayyar, H. (2016) Beneficial Elements for Agricultural Crops and Their Functional Relevance in Defense against Stresses. Archives of Agronomy and Soil Science, 62, 905-920. https://doi.org/10.1080/03650340.2015.1101070

[26] Potassium Nitrate. Mosaic Crop Nutrition, Mosaic Crop Nutrition. http://www.cropnutrition.com/resource-library/potassium-nitrate

[27] Gerendás, J., et al. (1997) Physiological and Biochemical Processes Related to Ammonium Toxicity in Higher Plants. Zeitschrift Für Pflanzenernährung Und Bodenkunde, 160, 239-251. https://doi.org/10.1002/jpln.19971600218

[28] Tavakkoli, E., Rengasamy, P. and McDonald, G.K. (2010) High Concentrations of $\mathrm{Na}^{+}$and $\mathrm{Cl}^{-}$Ions in Soil Solution Have Simultaneous Detrimental Effects on Growth of Faba Bean under Salinity Stress. Journal of Experimental Botany, 61, 4449-4459. https://doi.org/10.1093/jxb/erq251

[29] Majeed, K. and Al-Hamzawi, A. (2010) Effect of Calcium Nitrate, Potassium Nitrate and Anfaton on Growth and Storability of Plastic Houses Cucumber (Cucumis sativus L. cv. Al-Hytham). American Journal of Plant Physiology, 5, 278-290. https://doi.org/10.3923/ajpp.2010.278.290

[30] Dabuxilatu, I.M. (2005) Interactive Effect of Salinity and Supplemental Calcium Application on Growth and Ionic Concentration of Soybean and Cucumber Plants. Soil Science and Plant Nutrition, 51, 549-555.

https://doi.org/10.1111/j.1747-0765.2005.tb00063.x 